\title{
Systemic factors are trophic in bypassed rat small intestine in the absence of luminal contents
}

\author{
V Albert, G P Young, C L Morton, P Robinson, P S Bhathal
}

\begin{abstract}
Mucosal histology, crypt cell proliferation and brush border enzymes were measured in rats with varying degrees of jejunoileal bypass, in order to compare the effect of systemic and luminal factors on adaptive growth and differentiation (brush border enzymes) in small intestinal epithelium. Eighty five percent jejunoileal bypass caused a functional short gut; in intestine remaining in continuity there were significant increases in segmental weight, villus area and crypt depth, compared with sham operated controls and $25 \%$ jejunoileal bypass rats. Despite villus cell hyperplasia in $85 \%$ bypass rats, mucosal sucrase and alkaline phosphatase fell in jejunum and remained low in ileum, while leucine amino peptidase rose in ileum. There was a significant fall in villus area $(p<0.01)$ and crypt cell production $(\mathbf{p}<0.001)$ in self emptying loops of $25 \%$ bypass rats not exposed to luminal contents compared with control segments of sham operated rats. In contrast, self emptying loops of $85 \%$ bypass rats were not atrophied despite the much greater distance from luminal nutrients; the villus area $(p<0.01)$ and crypt cell production $(p<0.005)$ were higher than in $25 \%$ bypass rats, and at least as great as in sham operated rats. These results indicate that adaptive hyperplasia has a variable effect on expression of brush border enzymes which might reflect villus cell immaturity. The atrophic effect of diversion of luminal contents can be counteracted by systemic growth factors released as part of the adaptive response; thus systemic growth factors are not dependent on a permissive effect of luminal contents.
\end{abstract}

Compensatory structural and functional changes occur in the small intestine after bypass or resectional surgery. In segments left exposed to luminal contents after extensive resection there is an increase in both epithelial cell proliferation rate in the crypts and migration rate of these cells onto the villi, resulting in enlarged villi. ${ }^{1-3}$ Functionally, these segments exhibit increased absorptive capacity per unit length. ${ }^{1}$

The mechanisms by which these adaptive changes take place are complex and only understood in broad physiological terms. Luminal factors such as nutrients and pancreaticobiliary secretions are important in maintenance of cell proliferation in the small intestine in mammals. ${ }^{48}$ Systemic, circulating factors may also influence mucosal morphology and cell proliferation. ${ }^{9-12}$ As yet, no specific factor(s) has been conclusively identified although enteroglucagon has been implicated..$^{13}$ Epidermal growth factor has a potential role, ${ }^{14}$ but may act through the lumen rather than systemically. ${ }^{15}$ While it has been concluded that both systemic and luminal factors are involved in adaptation of the shortened gut, the relative importance of each is unknown. ${ }^{16}$ It has been concluded that systemic factors play only a permissive role, ${ }^{11}$ but it remains uncertain whether systemic factors are trophic in the absence of any luminal contents.

Jejunoileal bypass in which bypassed intestine is retained as a self-emptying loop, and similar models of intestinal adaptation, offer the opportunity to test the influence of systemic factors on intestinal epithelial proliferation relative to luminal factors, as all intestine remains exposed to the same systemic factors. Jejunoileal bypass produces hypertrophy of the gut left in continuity and exposed to luminal contents, the extent being proportional to the degree of bypass. ${ }^{17}$ The histology of self emptying loops created by the bypass has been reported to show a variety of changes: either atrophy ${ }^{217-20}$ or hypertrophy. ${ }^{31-22}$ Whether these changes result from an alteration in cell proliferation or in life span of villus cells is not clear. The relationship between the degree of atrophy or hypertrophy of the self emptying loop and the extent of the jejunoileal bypass - that is, the degree of shortening of incontinuity gut, has not been studied. If systemic growth factors were present in jejunoileal bypass, then these might stimulate cell proliferation in self emptying loops and so counteract the atrophic effect of diversion of luminal contents on mucosa of self emptying loops, depending on the relative importance of each influence.

The aim of this study was to determine the importance of systemic factors versus luminal factors and their influence on epithelial morphology and cell proliferation of rat small intestine. Villus area and crypt cell production were measured and compared in intestinal segments in rats subjected to $85 \%$ and $25 \%$ jejunoileal bypass. The maturity or extent of differentiation of epithelial cells was also determined by measuring the brush border enzymes, alkaline phosphatase, sucrase, and leucine aminopeptidase.

\section{Methods}

RATS

Male Sprague-Dawley rats of approximately $200 \mathrm{~g}$ were divided into three groups of seven which underwent the following operations (Fig 1):

The jejunum was transected $6 \mathrm{~cm}$ distal to the

\author{
Young MD, FRACP \\ University of Melbourne \\ Royal Melbourne Hospital, \\ Accepted for publication \\ 22 May 1989 \\ Department of Medicine \\ Anatomical Pathology \\ The Royal Melbourn \\ Australia \\ PRobinson
}




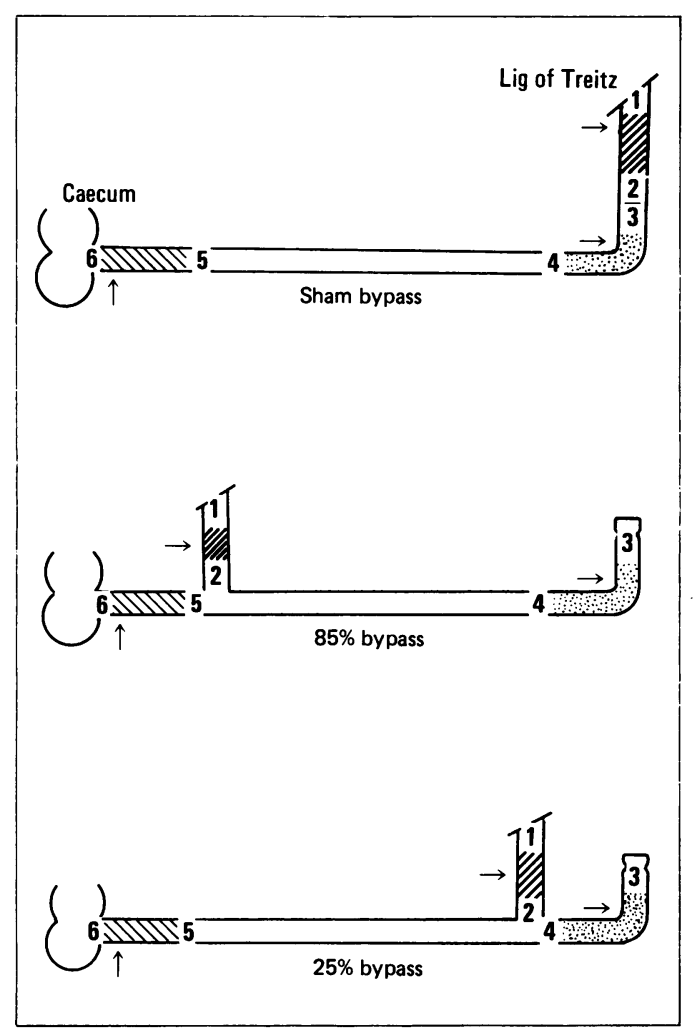

Figure 1: Diagrammatic representation of gut segments studied in the sham operated, $85 \%$ and $25 \%$ jejunoileal bypass rats. The $85 \%$ bypass has an extensive bypass creating a long self emptying loop, relative to the shorter $25 \%$ bypass loop. Segment 1-2 represents the segments designated jejunum, 3-4 the self emptying loop (SEL) and 5-6 the ileum. Arrows in each region indicate the $1 \mathrm{~cm}$ segments taken for histology with the adjacent $3 \mathrm{~cm}$ segment being used for enzyme assay. In the $S E L$ the segments for histology and measurement of crypt cell production rate were taken $1 \mathrm{~cm}$ away from the blind end and then a further $15 \mathrm{~cm}$ closer to the anastomosis.

duodenojejunal flexure and simply reanastomosed.

\section{EIGHTY FIVE PERCENT JEJUNOILEAL BYPASS}

The jejunum was transected $6 \mathrm{~cm}$ distal to the duodenojejunal flexure and the proximal end of the transected jejunum anastomosed, end-toside, to the ileum $10 \mathrm{~cm}$ proximal to the caecum. The distal cut end was oversewn. ${ }^{23}$

\section{TWENTY FIVE PERCENT BYPASS}

As for $85 \%$ bypass, but the anastomosis was established approximately $25 \mathrm{~cm}$ distal to the site of transection.

Rats drank only $5 \%$ glucose and water for $24 \mathrm{~h}$ before surgery. Surgery was performed under barbiturate anaesthesia (Nembutal, $60 \mathrm{mg} / \mathrm{kg}$, Ceval Chemicals Australia Pty Ltd, Hornsby, NSW). Postoperatively, rats fed freely on rat chow (Clarke King and Co, North Melbourne, Australia). The rate of postoperative weight gain in $85 \%$ bypass rats was never less than $90 \%$ that of sham operated rats; $25 \%$ bypass rats gained weight in parallel with sham operated rats. The $85 \%$ bypass rats were weight and age matched to control rats and weighed every two days for 80 days postoperatively. Rats were killed 12 weeks after surgery by carbon dioxide asphyxiation and the entire length of small intestine removed and irrigated with ice cold saline. The weight per unit length of standardised segments of jejunum, ileum and the end of self emptying loops was estimated by measuring ice cooled segments allowed to hang with a $10 \mathrm{~g}$ weight attached to the end. After opening the intestine longitudinally, standardised $1 \mathrm{~cm}$ segments were taken for histologic examination (Fig 1). This study was approved by the animal ethics committee of The Royal Melbourne Hospital.

\section{HISTOLOGY}

Tissue was fixed and processed for paraffin sectioning. Serial sections $(3 \mu \mathrm{m})$ were cut both longitudinal and transverse to the long axis of the gut, and were stained with $\mathrm{H} \& \mathrm{E}$.

\section{VILLUS AREA INDEX}

Villus height (VH), crypt depth (CD) and villus base width, measured in planes both longitudinal (BWL) and transverse (BWT) to the direction of flow down the gut, were determined using a micrometer eyepiece. An index of the villus area (VAI) as a measure of villus cell mass ${ }^{24}$ was calculated according to:

$$
\mathrm{VAI}=(\mathrm{BWL}+\mathrm{BWT}) \times \mathrm{VH}
$$

Measurements were made on 20 complete villi and 20 entire crypts randomly selected from histological sections from each gut segment. Only optimally sectioned crypts were counted that is, those with crypt lumen in full view from the base to the mouth of the crypt. The crypt mouth was defined as the position at which cell nuclei changed from a midcellular to basal position.

\section{CRYPT CELL PRODUCTION RATE INDEX}

Vincristine sulphate (David Bull, Laboratory, Melbourne, Australia) was given to rats by ip injection ( $1 \mathrm{mg} / \mathrm{kg}$ of body weight) to arrest cells in metaphase. The rats were killed at $1,1 \cdot 5,2,3$ and 3.5 or 4 hours after injection. The injection times were staggered to enable the animals to be killed over a period of two hours and so minimise circadian variations in both enzyme activity and crypt cell production rate. Counts of arrested metaphases per crypt were obtained from longitudinally orientated histological sections; 50 crypts were counted per segment per rat. The number of arrested metaphases per crypt was plotted against time and the crypt cell production rate index calculated from the slope of this line. The crypt cell production rate index was determined close to the blind end of the self emptying loops and in the mid-self emptying loops region (Fig 1).

\section{ASSAYS}

Brush border enzyme activities were determined in standardised segments adjacent to those taken for histology from proximal jejunum, distal ileum and blind end of the self emptying loops in bypass rate and corresponding segments in sham operated rats (Fig 1). Intestinal segments were laid on an ice-cold glass plate and then the external surface scraped with a glass slide to 
TABLE I Weight per unit length in intestinal segments from bypass and sham operated rats

\begin{tabular}{|c|c|c|c|c|c|}
\hline \multirow[t]{2}{*}{ Site } & \multicolumn{5}{|l|}{ Weight } \\
\hline & $\begin{array}{l}\text { Sham } \\
(\mathrm{mg} / \mathrm{cm})\end{array}$ & $\begin{array}{l}85 \% \text {-bypass } \\
(\mathrm{mg} / \mathrm{cm})\end{array}$ & $p$ & $\begin{array}{l}25 \% \text {-bypass } \\
(\mathrm{mg} / \mathrm{cm})\end{array}$ & $p$ \\
\hline $\begin{array}{l}\mathrm{N}= \\
\text { Jejunum }\end{array}$ & \multirow{3}{*}{$\begin{array}{l}7 \\
81 \cdot 23^{\star} \\
(4 \cdot 00) \\
72 \cdot 01 \\
(5 \cdot 53) \\
84 \cdot 88 \\
(4 \cdot 90)\end{array}$} & \multirow{3}{*}{$\begin{array}{l}7 \\
125 \cdot 60 \\
(13 \cdot 80) \\
195 \cdot 00 \\
(18 \cdot 90) \\
81 \cdot 11 \\
(9 \cdot 62)\end{array}$} & $<0.01$ & \multirow{3}{*}{$\begin{array}{l}6 \\
83 \cdot 82 \\
(3 \cdot 22) \\
84 \cdot 40 \dagger \\
(4 \cdot 52) \\
53 \cdot 22 \$ \\
(4 \cdot 12)\end{array}$} & NS \\
\hline Ileum & & & $<0.001$ & & NS \\
\hline SEL $\ddagger$ & & & NS & & $<0.01$ \\
\hline
\end{tabular}

$\star$ Mean (SEM); p refers to comparison with sham group, NS - not significant $(>0.05)$. $\nmid 25 \% v 85 \% \mathrm{p}<0.001, \ddagger$ SEL - self emptying loop, $\$ 25 \% v 85 \% \mathrm{p}<0.01$. of the jejunum $(\mathrm{p}<0.01)$ and a $170 \%$ increase in the ileum $(\mathrm{p}<0.001)$ when compared with sham operated rats (Table I). No significant increases were observed in comparable segments remaining in continuity of $25 \%$ bypass rats. Unlike the $25 \%$ bypass self emptying loops which atrophied, as shown by $37 \%$ decrease in weight per unit length $(p<0.01$, Table $I)$, the $85 \%$ bypass self emptying loops retained a similar weight to the sham operated rats. Macroscopic examination indicated that the self emptying loops were empty and the anastomoses clear from obstruction.

extrude the mucosa. A 5\% homogenate was then prepared in $50 \mathrm{mmol} / 1 \mathrm{mannitol}, 10 \mathrm{mmol} / 1 \mathrm{Tris}$. $\mathrm{HCl}, \mathrm{pH} 7 \cdot 4$, using a Waring blender. ${ }^{23}$ Alkaline phosphatase and protein were assayed as described. ${ }^{25}$ Sucrase was assayed by the method described by Dahlqvist ${ }^{26}$ and leucine aminopeptidase according to Muira et al. ${ }^{27}$

\section{STATISICAL ANALYSIS}

Small intestinal segment weights, villus height, crypt depth and villus area results were analysed by analysis of variance, and intergroup comparisons were tested with the Studentised NewmanKeuls test. The CCPR was determined by regression against time of number of arrested metaphases per sectioned crypt, using the Minitab computer program (Minitab Inc, University Park, PA). Crypt cell production rate slopes were compared using an analysis of covariance. ${ }^{28}$

\section{Results}

SEGMENTAL WEIGHT

Intestinal segments in $85 \%$ jejunoileal bypass rats remaining exposed to luminal contents, showed a $55 \%$ increase in the weight/unit length

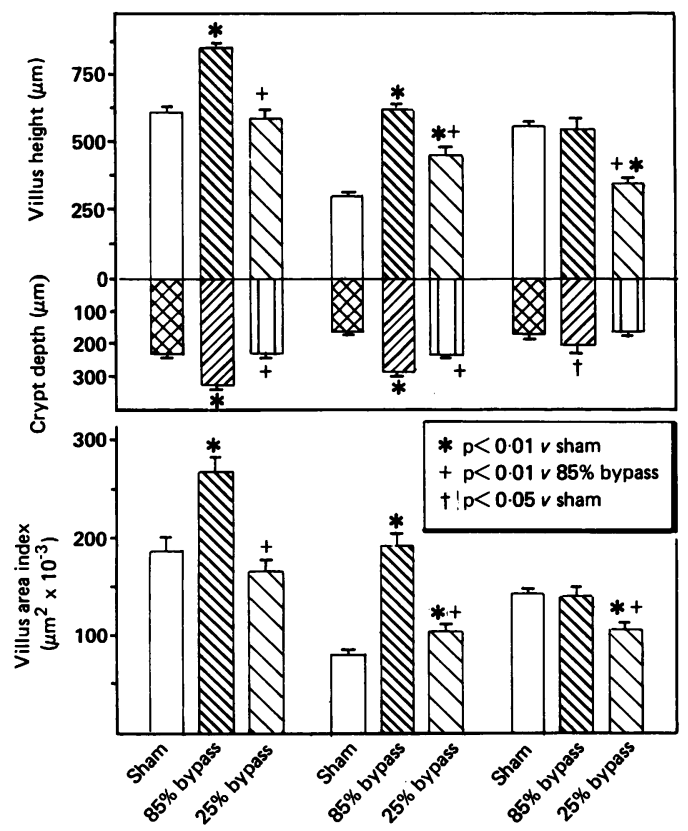

Figure 2: Morphometric measurements in comparable gut segments of $85 \%$ bypass, $25 \%$ bypass and sham operated (Sham) rats. Vertical bars show the SEM.

\section{MORPHOLOGY}

In the $85 \%$ bypass rats, histological examination confirmed adaptive hypertrophy in both jejunum and ileum (Fig 2); this was proportionally more marked in the ileum. The villus area index increased by $42 \%$ in the jejunum $(p<0.001)$ and $133 \%$ in the ileum $(p<0.001)$ compared to the sham operated rats. The villus area index in the self emptying loops of $85 \%$ bypass rats was similar to control segments in sham operated rats, however note that the crypt depth increased by $22 \%(\mathrm{p}<0.05)$.

In rats subjected to $25 \%$ bypass there was a mild, but significant, adaptive hypertrophy in ileum, with a $28 \%$ increase in villus area index $(\mathrm{p}<0.01)$. The jejunum remained similar to the sham operated rats (Fig 2). In the self emptying loops of $25 \%$ bypass rats there was $25 \%$ decrease $(\mathrm{p}<0.01)$ in the villus area index and no significant change in crypt depth in comparison to sham operated rats.

\section{CRYPT CELL PROLIFERATION}

Metaphase accumulation was linear with time over the experimental period at both the end of the self emptying loops, which originally was proximal jejunum, (Fig 3a) and the mid-self emptyng loops region (Fig $3 \mathrm{~b}$ ). There was no apparent lag in the onset of vincristine metaphase arrest. The rate of metaphase accumulation, or crypt cell production rate, was determined from the gradient of the regression line. The rates at the end of the self emptying loops were: $85 \%$ bypass $-3.58(1.57)$ metaphase arrests/crypt/ hour $/( \pm 95 \%$ confidence interval $)$, sham operated $-3.01(0.50), 25 \%$ bypass $-1.88(0.27)$. The rates in the mid-self emptying loops were: $85 \%$ bypass $-3.39(1.08)$, sham operated -3.20 $(0 \cdot 37), 25 \%$ bypass $-2.25(1 \cdot 57)$. In each experimental situation, the crypt cell production rates at the end of the self emptying loops were similar to those at the mid-self emptying loops region. The crypt cell production rate in $85 \%$ self emptying loops was increased compared to $25 \%$ bypass rats at both the end of the self emptying loops $(p<0.005)$ and the mid-self emptying loops region $(\mathrm{p}<0.05)$. In both sites the crypt cell production rate index in $85 \%$ bypass rats was equal to or higher than that of sham operated rats. 

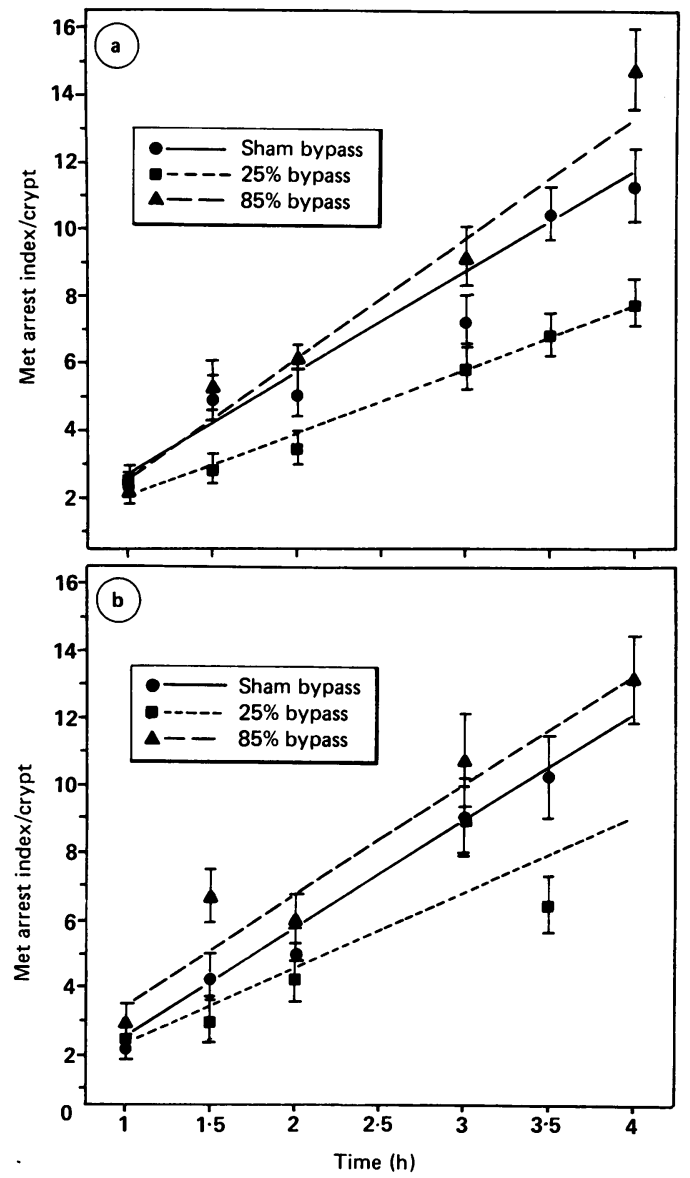

Figure 3: Metaphase accumulation with time at the blind end of the self emptying loop $(A)$ and the mid-loop region $(B)$. The slopes of the regression lines represent the rate of accumulated metaphases or crypt cell production rate, in each experimental group. Vertical bars represent $95 \%$ confidence intervals.

activity in mucosal homogenates and villus area index of $85 \%$ bypass and sham operated rats is shown in Figure 4 . In jejunum of $85 \%$ bypassed rats, activities of alkaline phosphatase $(\mathrm{p}<0.05)$, and sucrase $(\mathrm{p}<0.01)$ fell (Table II). In ileum, despite the doubling of villus area index to levels normally encountered in the jejunum, there was no significant increase in alkaline phosphatase or sucrase activity from the normally low ileal activities. Alkaline phosphatase and

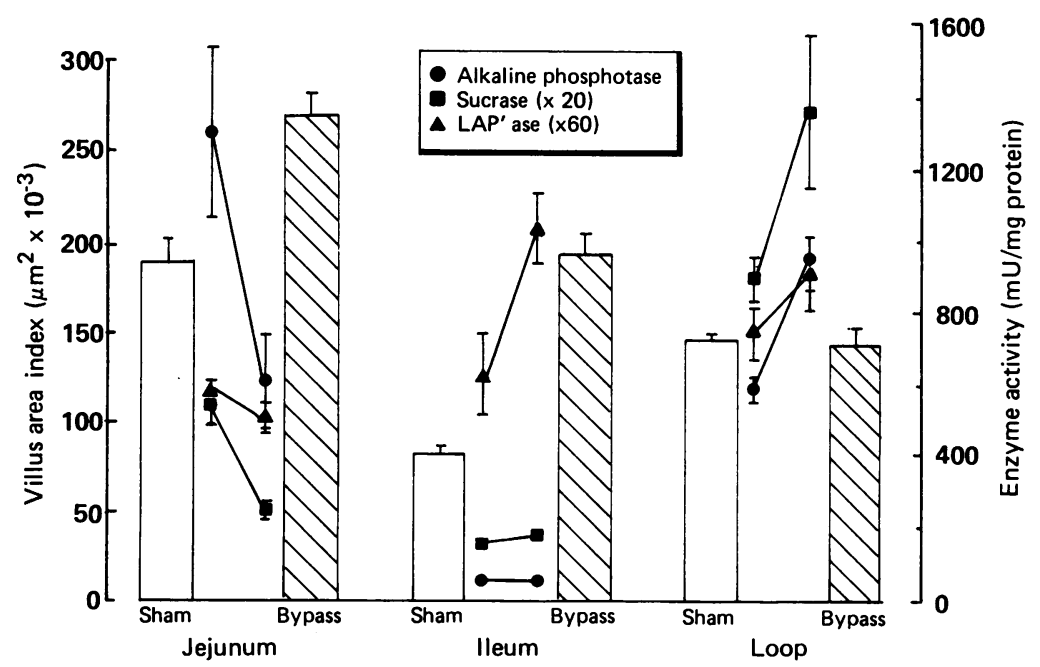

Figure 4: Relationship between villus area index and brush border enzyme activities in $85 \%$ bypass and sham operated rat intestinal segments. Vertical bars represent SEM. sucrase activities increased slightly, but significantly, in the $85 \%$ self emptying loops, even though the villus area index was similar to the sham operated rats. Leucine aminopeptidase activity was affected differently in that it increased in hypertrophied ileal mucosa, but remained essentially unchanged in other segments. Rats with a $25 \%$ bypass had increased activity of alkaline phosphatase in the jejunum $(p<0.05$ relative to sham operated rats, with all other enzyme activities remaining similar to controls (Table II).

\section{Discussion}

The findings show that diversion of luminal contents during the creation of self emptying bypassed loops does not necessarily cause atrophy. Significant atrophy did occur in self emptying loops of animals subjected to a modest $25 \%$ bypass, but not in the longer self emptying loops of rats subjected to extensive $85 \%$ bypass. Low crypt cell production rates and relatively shallow crypts were seen in self emptying loops of $25 \%$ bypass rats, while crypt cell production rate and crypt depth were maintained at normal and above normal respectively in self emptying loops of the $85 \%$ bypass rats. Thus, atrophy in these self emptying loops is prevented by maintenance of cell proliferation.

Rats subjected to $85 \%$ bypass showed the typical changes created by surgical shortening of the gut without bypass ${ }^{1729}$ of marked ileal and modest jejunal hypertrophy. Shortening of the gut in $25 \%$ bypass rats caused mild hypertrophy only in ileum. It seems likely, therefore, that the growth stimulus responsible for adaptive hypertrophy in $85 \%$ bypass rats is also the factor which prevents atrophy by maintaining cell proliferation in self emptying loops. Thus, variation in extent of bypass could explain varying reports of histology in self emptying loops in previous studies. ${ }^{23}$ 17-22

The mechanism responsible for increased crypt cell proliferation in short gut syndrome is uncertain. One hypothesis is that malabsorbed nutrients release growth factors from distal intestine, these enter the systemic circulation and so are delivered to the entire gut."13132 Enteroglucagon has been implicated as the growth factor by a body of indirect evidence, ${ }^{131}$ but a recent study in which antibodies were used to block its action have not supported this. ${ }^{33}$

An alternative mechanism involves the local release of high concentrations of paracrine growth factors by nutrient rich luminal contents presented to mucosa not normally exposed to such substances - namely distal ileum in short gut syndrome. It is known that ingestion of food maintains normal morphology and prevents atrophy $^{3+35}$ and that epithelial cells directly obtain nutrients from the lumen. ${ }^{36}$ The proliferative effect of nutrients, however, need not simply be a matter of ready availability of metabolic fuels as indicated by the work of Weser et al. ${ }^{8}$ They showed that segmental intraluminal administration of nutrients to fasted rats caused an increase in mucosal cell mass in perfused segments, but growth effects also occurred in more proximal segments not being 
TABLE II Brush border enzyme activities in mucosal homogenates ${ }^{\star}$ obtained from intestinal segments of bypass operated and sham operated rats

\begin{tabular}{|c|c|c|c|c|c|c|}
\hline & $\begin{array}{l}\text { Alk } \\
\text { phosphatase } \\
(m U / m g)\end{array}$ & $p$ & $\begin{array}{l}\text { Sucrase } \\
(m U / m g)\end{array}$ & $p$ & $\begin{array}{l}\text { Amino- } \\
\text { peptidase } \\
(\mathrm{mU} / \mathrm{mg})\end{array}$ & $p$ \\
\hline \multicolumn{7}{|l|}{ Jejunum } \\
\hline $85 \%$ bypass & $615(130)$ & 0.005 & $13(1)$ & 0.009 & $9(1)$ & $0 \cdot 15$ \\
\hline $25 \%$ bypass & $1565(68)$ & 0.03 & $28(2)$ & 0.59 & $8(1)$ & $0 \cdot 14$ \\
\hline sham & $1301(234)$ & - & $28(2)$ & - & $10(1)$ & - \\
\hline \multicolumn{7}{|l|}{ Ileum } \\
\hline $85 \%$ bypass & $66(11)$ & 0.41 & $9(1)$ & $0 \cdot 17$ & $17(2)$ & 0.08 \\
\hline $25 \%$ bypass & $66(16)$ & 0.28 & $6(2)$ & $0 \cdot 16$ & $9(1)$ & $0 \cdot 29$ \\
\hline sham & $61(13)$ & - & $8(1)$ & - & $10(2)$ & - \\
\hline \multicolumn{7}{|l|}{ SEL } \\
\hline $85 \%$ bypass & $964(92)$ & & $68(11)$ & 0.035 & $15(2)$ & $0 \cdot 16$ \\
\hline $25 \%$ bypass & $868(170)$ & 0.06 & $71(15)$ & 0.05 & $15(2)$ & 0.18 \\
\hline sham & $593(33)$ & - & $45(3)$ & - & $13(1)$ & - \\
\hline
\end{tabular}

^Expressed as mU/mg mucosal protein (mean $(\mathrm{SEM}))$. $\mathrm{p}$ value refers to comparison with sham group.

perfused. ${ }^{8}$ While luminal nutrients had a local growth effect, be it direct or indirect, they also led to growth factor entering the systemic circulation. Thus systemic growth factor might simply be an epiphenomen of the adaptive response, and not the main mechanism.

If the nutrient value of luminal contents were to be the principal mechanism for stimulation of crypt cell production rate in short gut syndrome, then we would expect atrophy and decreased crypt cell production rate in diverted self emptying loops no matter how short the functional gut. In this study crypt cell production rate and villus morphology were maintained in the long self emptying loops of rats with an $85 \%$ anatomically shortened gut. Thus, systemic, non-luminal growth factors are able to overcome the lack of luminal nutrients and other stimuli. This has a number of important implications. Systemic administration of a growth factor for therapeutic reasons in short gut syndrome even before commencing enteral nutrition, may prove of use. More importantly, it is feasible to test putative systemic growth factors by infusion into parenterally nourished animals, since the presence of luminal nutrients is not critical for a proliferative response.

Adaptive enlargement of villi, creating more enterocytes, need not necessarily imply optimisation of functional capacity of these cells. While absorption of glucose is increased per unit length,' this may simply result from increased villus cell mass as reflected in the increased villus area seen in this study. One indicator of villus cell functional capacity is the expression of brush border enzymes. Alkaline phosphatase is a good indicator of differentiation as cells towards the tip of the villus show highest levels of enzyme. ${ }^{37-}$ ${ }^{39}$ Sucrase-isomaltase is well expressed by villus cells of all ages, but not crypt cells. In this study, expression of each of these differentiation markers altered with changes in morphology, especially after $85 \%$ bypass. Alkaline phosphatase and sucrase activity fell in hypertrophied jejunum when expressed relative to mucosal protein. Similar effects were observed by McCarthy $e t a l^{40}$ for sucrase and by Wilson $e t a l^{41}$ and Menge et $a b^{30}$ for disaccharidases and/or alkaline phosphatase. As previously observed, ${ }^{3041}$ neither sucrase or alkaline phosphatase fell in ileum despite the marked increase in villus height; these enzymes are normally very low in activity in ileum. These changes suggest that villus cells are relatively immature in this model of adaptive hypertrophy and that growth factorinduced cell proliferation does not commit cells to improved functional differentiation.

In contrast with sucrase and alkaline phosphatase, leucine aminopeptidase activity increased in hypertrophied ileum, although not in jejunum. This would suggest a selective effect on that enzyme, possibly because of increased luminal protein in the ileum. It has been shown that brush border peptide hydrolase activity is induced by protein rich diets. ${ }^{42}$

Pancreatic enzymes are known to hasten turnover of brush border enzymes and reduce their activity. ${ }^{43}$ This might explain the modest increase in activities in the self emptying loops, but is unlikely to explain the falls in jejunal alkaline phosphatase and sucrase, as this region is normally exposed to pancreatic secretions anyway, and there was no apparent adverse effect on leucine aminopeptidase in the ileum.

While multiple studies ${ }^{30-41}$ have supported our findings of reduced expression of sucrase and alkaline phophatase in hypertrophied jejunum, Chaves et al, ${ }^{+4}$ using quantitative histochemical measures, have shown apparent increases in enzyme activities in hyperplastic jejunum in the short gut syndrome. While such a technique provides relative measures within a single tissue section, there is uncertainty about the validity of comparison between sections obtained from different animals under different experimental conditions. Keelan $e t a l^{45}$ found alkaline phosphatase activity to be increased in jejunal brush border preparations isolated from hypertrophied rabbit gut, although sucrase was unchanged. They concluded that cells of hypertrophied villi were not immature, even though their data gave no indication concerning the amount of enzyme per cell. Until cellular transport capacities or content of brush border enzymes are measured in cells isolated from along the length of the villus in each experimental setting, it will not be possible to determine the functional differentiation of villus cells.

Both cell proliferation and differentiation might be affected in bypassed loops by bacterial activity. ${ }^{76}{ }^{47}$ In a study of luminal bacteria in rats subjected to jejunoileal bypass, Viddal et $a l^{48}$ found the proximal part of the self emptying loops (near the blind end) to contain very low numbers of bacteria, while the distal part close to the anastomosis was populated by bacteria similar to those in the gut remaining in continuity. In that study, enzyme activities in the self emptying loops were slightly raised compared with control segments, confirming our findings and those of Menge et al. ${ }^{249}$ Thus the changes in proliferation observed in the self emptying loops were unlikely to have been caused by luminal flora.

In conclusion, atrophy does not occur in jejunal self emptying loops after extensive (85\%) jejunoileal bypass because crypt cell proliferation is maintained in the self emptying loops. Thus, the atrophic effect of diversion of luminal nutrients can be counteracted by growth factors which must be systemic. Consequently, luminal factors are not essential for maintenance of normal cellular turnover when there is a powerful stimulus to cell proliferation. Adaptive 
crypt cell proliferation does not appear to commit cells to full functional differentiation on the villi, although additional studies are needed to establish this with certainty.

The financial support of the National Health and Medical Research Council of Australia is gratefully acknowledged. The authors wish to thank Dr P Tutton for advice about the metaphase arrest technique. We also wish to thank the staff of the Department of Anatomy, University of Melbourne, and of the Department of Anatomical Pathology, the Royal Melbourne Hospital, for assistance with preparation of histological sections. A portion of this work was presented at the Third International Conference on Intestinal and Pancreatic Adaptation, Titisee, West Germany, June 1986.

1 Dowling RH, Booth CC. Structural and functional changes following small intestinal resection in the rat. Clin Sci 1967; 32: 139-49.

2 Menge $H$, Block $R$, Schaumloffel E, Riecken EO. Transportstudien, morphologische, morphometrische und histochemische Untersuchungen zum Verhalten der histochemische Untersuchungen zum Verhalten der Jejunalabschnitt der Ratte. Z Ges amle Exp Med 1970; 153: J4-90.

3 Tilson MD, Wright HK. Adaptation of functioning and bypassed segments of ileum during compensatory hypertrophy of the gut. Surgery $1970 ; 67: 687-3$.

4 Altmann GG. Influence of bile and pancreatic secretions on the size of intestinal villi in the rat. Am $\mathcal{F}$ Anat 1971; 132: 167 78.

5 Altmann GG. Influence of starvation and refeeding on mucosa size and epithelial renewal in the rat small intestine. $A m \mathcal{F}$ Anat 1972; 133: 391-400.

6 Feldman EJ, Dowling RH, McNaughton J, Peters TJ. Effects of oral versus intravenous nutrition on intestinal adaptation of oral versus intravenous nutrition on intestinal adaptation
after small bowel resection in the dog. Gastroenterology 1976; 70: 712-9.

7 Dowling RH. Small bowel adaptation and its regulation. Scand f Gastroenterol 1982; 17: 52-73.

8 Weser E, Babbitt J, Hoban M, Vandeventer A. Intestinal adaptation. Different growth responses to disaccharides compared with monosaccharides in rat small bowel. Gastroenterology 1986; 91: 1521-7.

9 Loran MR, Carbone JV. The humoral effect of intestinal resection on cellular proliferation and maturation in parabiotic rats. In: Sullivan MF. Gastrointestinal injury. Amsterdam: Experta Medica, 1968: 127-39.

10 Caussignac Y, David F. Humoral growth factor after small intestinal resection in the dog. Can $\mathcal{F}$ Physiol Pharmacol 1982; 60: 1322-5

$11 \mathrm{Li}$ AKC, Jeppson BW, Jamieson CE. Intraluminal versus humoral factors in intestinal cell proliferation. Br $\mathcal{J}$ Surg 1982; 69: 569-72.

12 Biller JA, Montgomery RK, Grand RJ, Klagsbrun M, Rosenthal A. Use of a 3T3 cell growth factor assay for the delineation and characterization of humoral trophic factors involved in intestinal adaptation in the rat. Gastroenterology 1986; 91: 448-55.

13 Bloom SR. Gut hormones in adaptation. Gut 1987; 28 (Suppl): 31-5.

14 Goodlad RA, Wilson TJG, Lenton W, Gregory H, McCullagh KG, Wright NA. Proliferative effects of urogastrone-EGF on the intestinal epithelium. Gut 1987; 28: (Suppl) 37-43.

15 Ulshen MH, Lyn-Cook LE, Raasch RH. Effects of intraluminal epidermal growth factor on mucosal proliferation in the small intestine of adult rats. Gastroenterology 1986; 91: the small

16 Williamson RNC, Bucholtz TW, Malt RA. Humoral stimulation of cell proliferation in small bowel after
transection and resection in rats. Gasroenterology 1978; 75: transection $249-54$.

17 Fenyo G, Hallberg D. Intestinal hypertrophy after small intestinal bypass in the rat. Acta Chir Scand 1976; 142: 2619.

18 Gleeson $M H$, Cullen J, Dowling RH. Intestinal structure and function after small bowel bypass in the rat. Clin Sci 1972; 43: $731-42$.

19 Menge H, Bloch R, Schaumloffel E, Riecken EO. Jejunal bypass and reconstitution. In: Dowling RH. Intestinal adaptation. Stuttgart: Schattauer Verlag, 1974: 61-7.

20 Keren DF, Elliott HL, Brown GD et al. Atrophy of villi with hypertrophy and hyperplasia of Paneth cells in isolated (Thiry-vella) ileal loops in rabbits: light microscopic studies. Gastroenterology 1975; 68: 83-93.

21 Clark RM. Control of intestinal epithelial replacement: lack of evidence for a tissue specific blood-borne factor. Cell Tissue Kinet 1974; 7: 241-50.
22 Williamson RCN, Bauer FLR, Ross JS et al. Proximal enterectomy stimulates distal hyperplasia more than bypass or pancreaticobiliary diversion. Gastroenterology 1978; 74: 16-23.

23 Young GP, Morton CL, Rose IS, Taranto TM, Bhathal PS. Effects of intestinal adaptation on insulin binding to villus cell membanes. Gut 1987; 28 (Suppl): 57-62.

24 Wright NA, Irwin $M$. The kinetics of villus cell populations in the mouse small intestine. 1 . Normal villi: the steady state requirements. Cell Tissue Kinet 1982; 15: 595-609.

25 Young GP, Friedman S, Yedlin ST, Alpers DH. Effect of fat feeding on intestinal alkaline phosphatase activity in tissue and serum. Am $\mathcal{F}$ Physiol 1982; 241 461-8.

26 Dahlquist A. Assay of intestinal disaccharidases. Anal Biochem 1968; 22: 99-107.

27 Muira S, Morita A, Erickson .RH, Kim YS. Content and turnover of rat intestinal microvillus membrane aminopeptidase. Effect of methylprednisolene. Gastroenterology 1983; 85: 1340-9.

28 Snedecor GW, Cochran WG. Statistical methods. Ames, Iowa: Iowa State University Press, 1967: 258-443.

29 Williamson RCN. Intestinal adaptation, Structural, functional and cytokinetic changes. N Engl f Med 1978; 298: 1393402 .

30 Menge $\mathrm{H}$, Robinson JWL. The relationship between the structural and functional alterations in the rat small intestine following proximal resection of varying extents. Res Exp Med 1978; 173: 41-53.

31 Besterman HS, Adrian TE, Mallinson CN, et al. Gut hormone release after intestinal resection. Gut 1982; 23: 854-61.

32 Sagor GR, Ghatei MA, Al-Mukhtar MYT, Wright NA, Bloom SR. Evidence for a humoral mechanism after small intestinal resection. Exclusion of gastrin but not enteroglucagon. Gastroenterology 1983; 84: 902-6.

33 Gregor M, Menge H, Stossel R, Riecken EO. Effect of monoclonal antibodies to enteroglucagon on ileal adaptation after proximal small bowel resection. Gut 1987; 28 (Suppl): 9-14.

34 Weser E. Luminal nutrients and intestinal adaptation. $\mathcal{f}$ Pediatr Gastroenterol Nutr 1985; 4: 165-6.

35 Al-Jurf AS, Younoszai MK, Chapman-Furr F. Effect of nutritional method on adaptation of the intestinal remnant after massive bowel resection. $\mathcal{F}$ Pediatr Gastroenterol Nutr $1985 ; 4: 245-52$

36 Alpers DH. Protein synthesis in intestinal mucosa: the effect of route of administration of precursor amino acids. $\mathcal{f} \mathrm{Clin}$ Invest 1972; 51: 167-73.

37 Eloy R, Haffen K, Grenier JF. Enzymes in the normal and diseased small intestinal mucosa: development, localisation, secretion and control. Prog Gastroenterol 1977; 3: 439-79.

38 Van Dongen JM, Kooyman J, Visser WJ, Holt SJ, Galjaard H. The effect of increased crypt cell proliferation on the activity and subcellular localisation of esterases and alkaline phosphatase in the rat small intestine. Histochem $\mathcal{F}$ 1977; 9: phosphata

39 Young GP, Yedlin ST, Alpers DH. Distribution of soluble and membranous forms of alkaline phosphatase in the small intestine of the rat. Biochim Biophys Acta 1981; 676: 257-65.

40 McCarthy DM, Kim YS. Changes in sucrase, enterokinase and peptide hydrolase after intestinal resection. $\mathcal{F}$ Clin Invest 1973; 52: 942-51.

41 Wilson HD, Miller T, Ogesen B, Schedl HP, Failla ML, Loven DP. Adaptation of the duodenum and ileum of the rat to mid-gut resection: enzyme activity and trace metal status. Am f Clin Nutr1986; 43: 185-93.

42 McCarthy DM, Nicholson JA, Kim YS. Intestinal enzyme adaptation to normal diets of different composition. Am $\mathcal{F}$ Physiol 1980; 239: 445-51.

43 Alpers DH, Tedesco FJ. The possible role of pancreatic protease in the turnover of intestinal brush border proteins. protease in the turnover of intestinal bru
Biochem Biophys Acta $1975 ; 401: 28-40$.

44 Chaves M, Smith MW, Williamson RCN. Increased activity of digestive enzymes in ileal enterocytes adapting to proximal small bowel resection. Gut 1987; 28: 981-7.

45 Keelan M, Walker K, Thomson ABR. Resection of rabbit ileum: effect on brush border enzyme membrane markers and lipids. Can $\mathcal{F}$ Physiol Pharmacol 1985; 63: 1528-32.

46 Jonas A, Krishman C, Forstner G. Pathogenesis of mucosal injury in the blind loop syndrome. Gastroenterology 1978; 75:
$791-5$.

47 de Both NJ, Plaisier H. The influence of changing cell kinetics on functional differentiation in the small intestine of the rat. f Histochem Cytochem 1974; 22: 352-60.

48 Viddal KO, Midtvedt T, Nygaard K. Intestinal bypass. Bacteriological studies from different parts of the small Bacteriological studies from different parts of the smal
intestine in rats. Scand f Gastroenterol 1983; 18: 619-25.

49 Menge H, Robinson JWL, Shroeder P. Function and structure correlations in the atrophic mucosa of self emptying blind loops of rat small intestine. F Physiol 1978; 33P-34P. 